\title{
SISTEM INFORMASI GEOGRAFIS LAYANAN PUBLIK LINGKUP KOTA MAKASSAR BERBASIS WEB
}

\author{
Nurhajar Anugraha ${ }^{1}$, Randy Angriawan ${ }^{2}$, Mashud $^{3}$ \\ Teknik Informatika STMIK AKBA ${ }^{1,2}$ Sistem Informasi STMIK AKBA ${ }^{3}$ \\ nuhajar@akba.ac.id ${ }^{1}$, randy@akba.ac.id ${ }^{2}$, mashud@akba.ac.id ${ }^{3}$
}

\begin{abstract}
Abstrak. Perkembangan Sistem Informasi Geografis saat ini terus berkembang seiring kemajuan teknologi dan informasi khususnya dalam bidang informasi letak dan kondisi suatu wilayah. Sistem Informasi Geografis dibutuhkan untuk mengetahui berbagai informasi umum mengenai suatu lokasi. Pada penelitian ini, Sistem Informasi Geografis dibuat dengan tujuan membantu masyarakat untuk mengetahui layanan publik apa saja yang ada di lingkup kota Makassar. Perancangan dilakukan dengan menggunakan metode Linear Sequential Model (atau disebut juga "Classic Life Cycle" atau "Waterfall Model") yang merupakan metode pengembangan perangkat lunak dengan pendekatan sekuensial dengan cakupan aktivitas Rekayasa Sistem dan Analisis, Kebutuhan Perangkat Lunak, Perancangan (DeGISn), Pembuatan Coding, Pengujian (Testing) dan Perawatan (Maintenance). Aplikasi yang dibuat merupakan aplikasi berbasis web dengan menggunakan Bahasa program PHP. Hasil dari penelitian ini yaitu adanya aplikasi system informasi geografis layanan masyarakat lingkup kota Makassar berbasis website yang dapat mempermudah masyarakat dalam menemukan kantor-kantor pelayanan publik di kota Makassar.
\end{abstract}

Kata Kunci: Sistem Informasi Geografis, Layanan masyarakat, Makassar, Website

\begin{abstract}
The development of Geographic Information Systems is currently growing as technology and information progress, especially in the field of information on the location and condition of an area. Geographic Information Systems are needed to find out various general information about a location. In this study, the Geographic Information System was created with the aim of helping the public to know what public services exist in the city of Makassar. The design is done using the Linear Sequential Model method (also called "Classic Life Cycle" or "Waterfall Model") which is a software development method with a sequential approach with the scope of activities of Systems and Analysis Engineering, Software Requirements, Designing, Making Coding, Testing and Maintenance. The application created is a web-based application using the PHP program language. The results of this study are the application of a website-based geographical geographic service information system in the city of Makassar that can make it easier for people to find public service offices in the city of Makassar.
\end{abstract}

Keywords: Geographic Information System, Community Service, Makassar, Website

\section{Pendahuluan}

Kota Makassar adalah ibu kota provinsi Sulawesi Selatan. Makassar merupakan kota terbesar di kawasan Indonesia Timur dan wilayah metropolitan terbesar kedua di luar Pulau Jawa, setelah Kota Medan. Dari aspek pembangunan dan infrastruktur, kota Makassar tergolong salah satu kota terbesar di Indonesia dan dengan wilayah seluas 199,26 km² dan penduduk hampir mencapai 1,4 juta jiwa, kota ini berada di urutan kelima dalam hal jumlah penduduk setelah Jakarta, Surabaya, Bandung dan Medan. Dengan wilayah yang luas tersebut masyarakat yang masih awam dengan lokasi - lokasi di Kotamadya Makassar tentu masih akan kesulitan untuk mencari tempat atau alamat yang diinginkan.

Hal ini dikarenakan tidak adanya fasilitas tambahan lainnya yang bisa membantu masyarakat luas untuk mencari lokasi atau mengidentifikasi suatu tempat layanan masyarakat seperti adanya gambar lokasi ataupun peta yang menunjukkan alamat tersebut. Seringkali informasi yang ditampilkan belum lengkap bahkan terkadang bangunan atau objek yang di cari belum tersedia, kekurangan ini ditambah dengan database tempat yang hanya di update 
setahun sekali. SIG dapat disajikan dalam bentuk aplikasi desktop maupun aplikasi berbasis web. SIG juga dapat memberikan penjelasan tentang suatu peristiwa, membuat peramalan kejadian, dan perencanaan strategis lainnya serta dapat membantu menganalisis permasalahan umum seperti masalah ekonomi, penduduk, sosial pemerintahan, pertahanan serta bidang pariwisata.

Berdasarkan latar belakang diatas maka dapat dirumuskan permasalahan bagaimana merancang suatu sistem informasi Georafis yang dapat menampilkan hasil pencarian tata letak suatu objek.

\section{Tinjauan Pustaka \\ Sistem Informasi Geografis (SIG)}

Teknologi Sistem Informasi Geografis (SIG) adalah sistem komputer yang terdiri dari proses mengumpulkan, memeriksa, mengintegrasikan, dan menganalisa informasi-informasi yang berhubungan dengan area permukaan bumi. Pada dasarnya, istilah sistem informasi geografi merupakan gabungan dari tiga unsur pokok yaitu sistem, informasi, dan geografi. Dengan demikian, pengertian terhadap ketiga unsur-unsur pokok ini akan sangat membantu dalam memahami SIG. Dengan melihat unsur-unsur pokoknya, maka jelas SIG merupakan salah satu sistem informasi. SIG merupakan suatu sistem yang menekankan pada unsur informasi geografi. Istilah "geografis" merupakan bagian dari spasial (keruangan). Kedua istilah ini sering digunakan secara bergantian atau tertukar hingga timbul istilah yang ketiga, geospasial. Ketiga istilah ini mengandung pengertian yang sama di dalam konteks SIG. Penggunaan kata "geografis" mengandung pengertian suatu persoalan mengenai bumi: permukaan dua atau tiga dimensi. Istilah "informasi geografis" mengandung pengertian informasi mengenai tempattempat yang terletak di permukaan bumi, pengetahuan mengenai posisi dimana suatu objek terletak di permukaan bumi, dan informasi mengenai keteranganketerangan (atribut) yang terdapat di permukaan bumi yang posisinya diberikan atau diketahui (Prahasta, 2002)
Adapun ciri-ciri SIG (Wibowo dkk., 2015) adalah sebagai berikut:

1. SIG memiliki sub sistem input data yang menampung dan dapat mengolah data spasial dari berbagai sumber. Sub sistem ini juga berisi proses transformasi data spasial yang berbeda jenisnya, misalnya dari peta kontur menjadi titik ketinggian.

2. SIG mempunyai subsistem penyimpanan dan pemanggilan data yang memungkinkan data spasial untuk dipanggil, diedit, dan diperbaharui.

3. SIG memiliki subsistem manipulasi dan analisis data yang menyajikan peran data, pengelompokan dan pemisahan, estimasi parameter dan hambatan, serta fungsi permodelan

4. SIG mempunyai subsistem pelaporan yang menyajikan seluruh atau sebagian dari basis data dalam bentuk tabel, grafis dan peta.

\section{PHP dan MySql}

PHP adalah bahasa pelengkap HTML yang memungkinkan dibuatnya aplikasi dinamis yang memungkinkan adanya pengolahan data dan pemrosesan data. Semua sintax yang diberikan akan sepenuhnya dijalankan pada server sedangkan yang dikirimkan ke browser hanya hasilnya saja. Kemudian merupakan bahasa berbentuk script yang ditempatkan dalam server dan diproses di server. Hasilnya akan dikirimkan ke client, tempat pemakai menggunakan browser. PHP dikenal sebagai sebuah bahasa scripting, yang menyatu dengan tag-tag HTML, dieksekusi di server, dan digunakan untuk membuat halaman web yang dinamis seperti halnya Active Server Pages (ASP) atau Java Server Pages (JSP). PHP merupakan sebuah software Open Source (TIM Ems, 2012)

MySQL merupakan suatu jenis database server yang sangat terkenal. MySQL termasuk jenis RDBMS (Relational Database Manajement System). MySQL mendukung bahasa pemrograman $\mathrm{PH}$, bahasa permintaan yang terstruktur, karena pada penggunaannya SQL memiliki berberapa aturan yang telah distandarkan oleh asosiasi yang bernama ANSI. MySQL merupakan RDBMS 
(Relational Database Management System) server. RDBMS adalah program yang memungkinkan pengguna database untuk membuat, mengelola, dan menggunakan data pada suatu model relational (Nugroho, 2011).

\section{Metode Perancangan Aplikasi GIS}

Pada rancangan penelitian ini digunakan metode Linear Sequential Model (atau disebut juga "Classic Life Cycle" atau "Waterfall Model") Linear sequential model ("classic life cycle" atau "waterfall model") adalah metode pengembangan perangkat lunak dengan pendekatan sekuensial dengan cakupan aktivitas:

1. Rekayasa Sistem dan Analisis. Perangkat lunak adalah bagian dari sistem yang lebih besar, pekerjaan dimulai dari pembentukan kebutuhan-kebutuhan untuk seluruh elemen sistem dan kemudian memilah mana yang untuk pengembangan perangkat lunak.

2. Analisis Kebutuhan Perangkat Lunak. Berfokus pada perangkat lunak, yang meliputi: domain informasi, fungsi yang dibutuhkan, unjuk kerja/performansi dan antarmuka.

3. Perancangan. Ada empat atribut untuk program, yaitu: Struktur Data, Arsitektur perangkat lunak, Prosedur detil, dan Karakteristik Antarmuka. Proses desain mengubah kebutuhankebutuhan menjadi berbagai bentuk karakteristik yang dapat dimengerti perangkat lunak sebelum dimulai penulisan program.

4. Pembuatan Kode (Coding). Merupakan proses penterjemahan perancangan ke bentuk yang dapat dimengerti oleh mesin, dengan menggunakan bahasa pemrograman sesuai dengan kebutuhan.

5. Pengujian (Testing). Setelah kode program selesai testing dapat dilakukan. Testing memfokuskan pada logika internal dari perangkat lunak, fungsi eksternal dan mencari segala kemungkinan kesalahan dan memeriksa apakah sistem yang dirancang sesuai dengan hasil yang diinginkan.
6. Pemeliharaan

(Maintenance). Merupakan bagian paling akhir dari siklus pengembangan dan dilakukan setelah perangkat lunak dipergunakan (Sommerville. 2004)

Adapun proses Linear Sequential Model atau Waterfall Model seperti yang dapat dilihat pada gambar 1 :

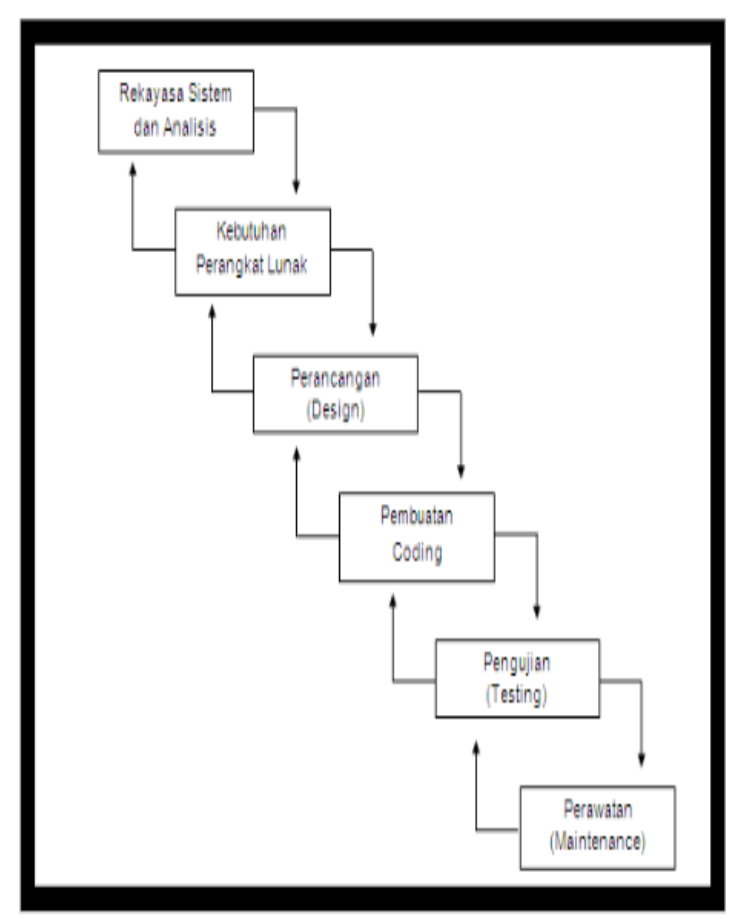

Gambar 1. Linear Sequential Model

1. Perancangan Proses Aplikasi

Tahapan perancangan dilakukan dengan membuat activity diagram, baik untuk Admin maupun untuk untuk User, seperti terlihat pada activity diagram pada gambar 2.

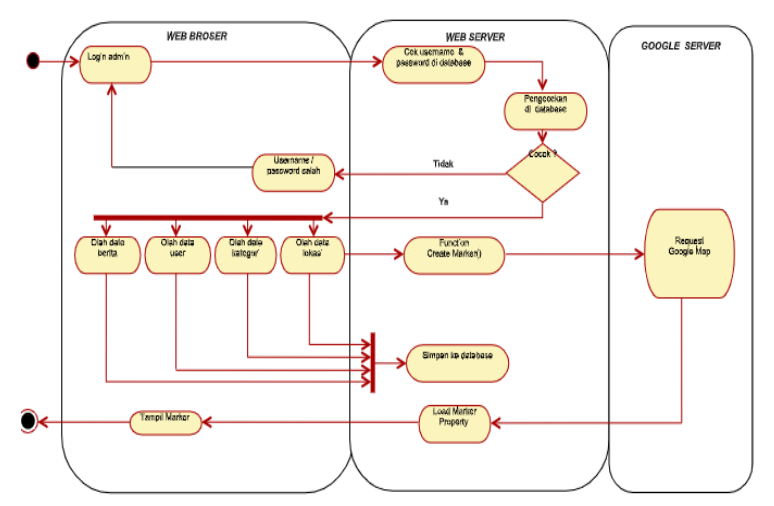

Gambar 2. Diagram Aktifitas Admin 


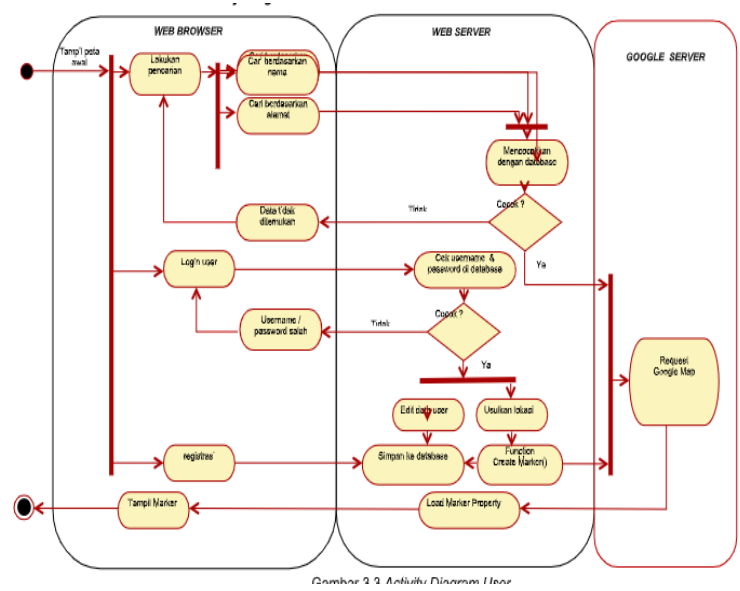

Gambar 3. Diagram Aktifitas User

2. Perancangan Interfca/Antarmuaka

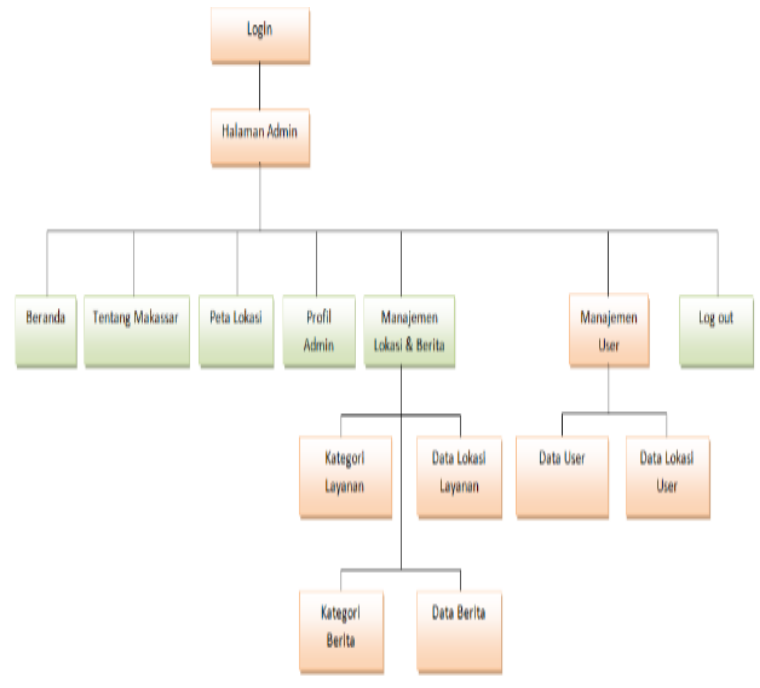

Gambar 4. Interface Halaman Admin

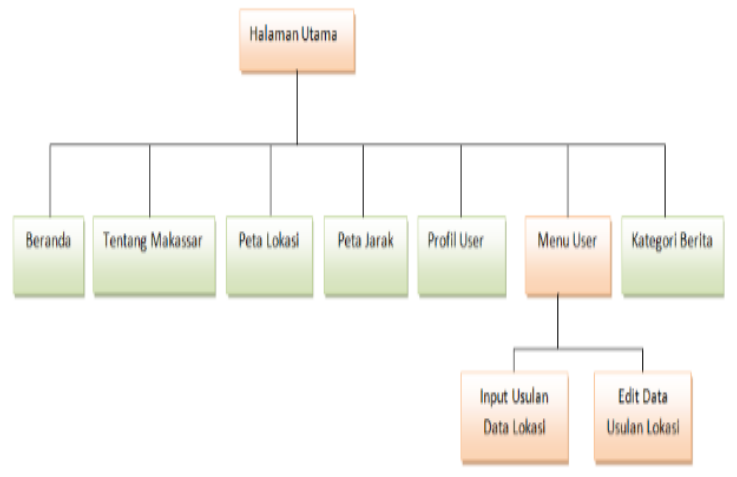

Gambar 5. Interface Halaman User Registred

\section{Hasil dan Pembahasan}

Pada bagian ini akan di bahas mengenai hasil dari Tampilan program yang telah di buat. Program yang telah di buat ini memiiki 2 pilihan Form halaman, halaman pertama untuk Administrator atau Admin dan halaman yang lain untuk User atau pengguna. Administrator atau Admin memegang hak kendali atas program, mulai dari menginput, mengelola, mengedit hingga menghapus data pada program. Sedangkan untuk User atau Pengguna terdapat 2 pilihan, User dapat memilih hanya sebagai “pengunjung' biasa dan User bisa mendaftarkan diri sebagai User Register dengan melakukan Sign up dan mengisi beberapa data yang diperlukan.

Keuntungan menjadi User terregistrasi adalah dapat menginput usulan data lokasi serta dapat memberi usulan untuk mengedit data lokasi jika Admin membuat kesalahan dalam menentukan titik lokasi.

\section{A. Halaman Admin}

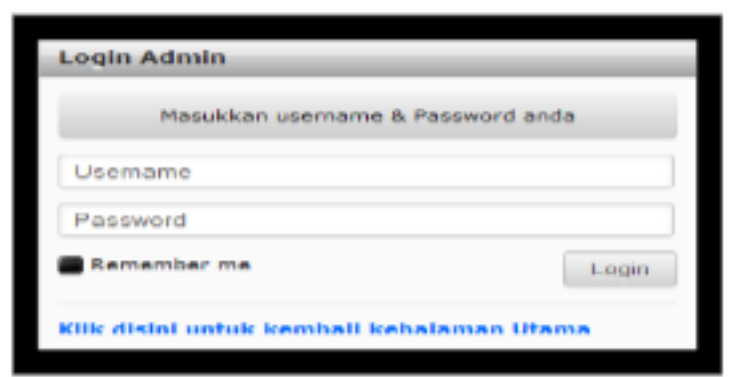

Gambar 6. Form Admin

Halaman ini merupakan kunci untuk menjaga keamanan isi dari interface administrator. Pada halaman ini terdapat kolom username dan password yang harus di isi oleh admin. Apabila admin salah memasukkan username ataupun password maka admin gagal untuk masuk ke interface administrator. Setelah memasukkan Username dan Password yang benar maka akan diarahkan ke halaman utama Admin seperti gambar dibawah. Halaman ini adalah halaman pertama yang tampil setelah admin berhasil login.Halaman User. 


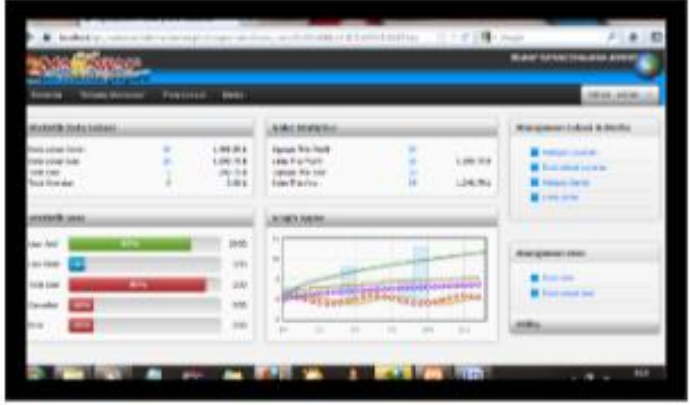

Gambar 7. Tampilan Halaman Admin setelah

Pada halaman Administrator terdiri dari beberapa menu pilihan seperti berikut ini : Menu beranda, Menu Tentang Makassar, Peta Lokasi, Profil Admin dan Logout. Setelah Logout sukses akan dialihkan ke halaman Login untuk Admin kembali atau dapat memilih untuk ke halaman utama. Selain itu pada Form Admin pun terdapat Manajemen Lokasi dan berita yang berisikan : Kategori layanan, Menu data lokasi, Menu kategori berita, Menu data berita dan Menu data User. Pada pembuatan dan perancangan program kali ini, kategori yang digunakan sebagai acuan hanya ada 8 jenis, yaitu ; Pusat Pendidikan, Layanan Kesehatan, Perkantoran, Pemakaman, Restaurant, Hotel / Penginapan, Transportasi, serta Hiburan dan Pusat Perbelanjaan. Program ini bekerja dengan menampilkan kategori apa yang di pilih Admin atau User, misalkan pada saat Icon Pusat Pendidikan ini di klik maka akan muncul semua sarana pendidikan yang ada di kota Makassar yang telah di Inputkan oleh Admin sebelumnya, begitupun untuk kategori lainnya. Apabila salah satu iconnya di klik maka yang muncul pada tampilan peta adalah data dari kategori yang dipilih dan yang telah di inputkan oleh Admin.

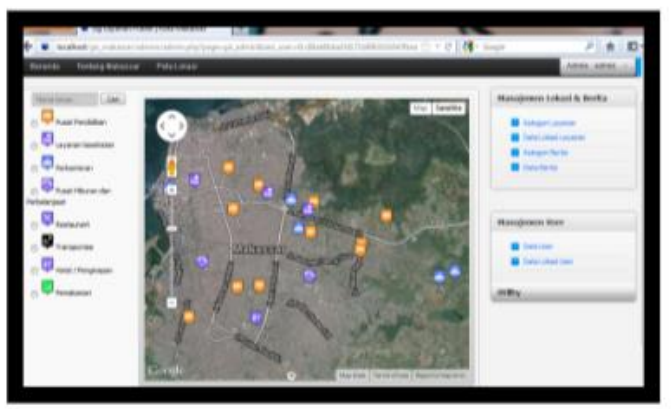

Gambar 8. Menu Peta Lokasi
B. Halaman User

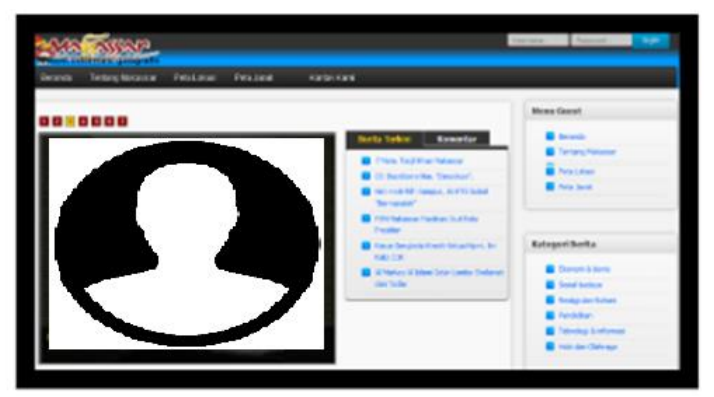

Gambar 9. Halaman Awal User

Gambar 9. menunjukkan Halaman Awal User, baik User Universal maupun User yang telah mendaftar menjadi member, pada Form diatas terdapat menu-menu sebagai berikut : Menu beranda, Menu tentang Makassar, Peta lokasi, Menu input usulan data lokasi, menu profil user dan menu logout.

Pada Menu halaman peta lokasi menampilkan peta digital danmenampilkan kategori lokasi layanan yang telah ditentukan dan icon yang berisi informasi lokasi layanan publik kota Makassar ketika di klik. Dimana pada awalnya semua kategori yang telah diinputkan akan muncul secara keseluruhan dan ketika User mengklik salah satu kategori, maka icon yang muncul akan sesuai dengan kategori yang dipilih, apakah Kategori Perguruan tinggi, Sekolah, Layanan kesehatan maupun Perkantoran. Saat User memilih satu lokasi dan mengkliknya, maka akan muncul Form deskripsi singkat mengenai tempat yang dipilih, berupa Foto, alamat, nomor telepon dan Informasi selengkapnya akan tampil saat User mengklik gambar yang di tampilkan.

\section{Kesimpulan}

Setelah melakukan perancangan dan pembuatan aplikasi "Sistem Informasi Geografis Layanan Masyarakat Lingkup Kota Makassar Berbasis Web" maka penulis dapat menyimpulkan :Sistem Informasi Geografis Layanan Masyarakat Lingkup Kota Makassar Berbasis Web yang telah di buat memiliki beberapa kelebihan antara lain :

1. Kemudahan dalam mencari suatu titik lokasi karena telah dilakukan 
pembagian kategori berdasarkan jenis lokasi

2. Adanya informasi lengkap mulai dari alamat, nomor telepon dan diskripsi tentang suatu titik lokasi.

3. Adanya informasi jarak dan rute yang ditampilkan saat User mengakses satu lokasi dengan lokasi yang lain dengan menggunakan Menu Peta Lokasi.

\section{Saran}

Dari proses perancangan hingga pembuatan aplikasi Sistem Informasi Geografis Layanan Masyarakat Lingkup Kota Makassar Berbasis Web ini tentu saja tidak terlepas dari kekurangan dan kelemahan, untuk itu Penulis berharap kedepannya program ini dapat lebih di sempurnakan khususnya dalam hal-hal berikut ini :

1. Penambahan lokasi pelayanan publik yang ada di kota Makassar lebih di lengkapi dan terus di update agar informasi yang sampai pada User bisa lebih terpercaya.

2. Pengembangan aplikasi ke sistem yang lebih populer, misalnya dapat di akses melalui program Android sehingga mempermudah user mengaksesnya.

\section{Daftar Pustaka}

Bunafit Nugroho, 2011. Membuat Sistem Informasi Penjualan Berbasis Web dengan PHP dan MySQL. Yokyakarta: Gava Media

Ian Sommerville. 2004. Software Engineering 7 th Edition, . Workingham: Addison Wesley

Koko Mukti Wibowo, dkk. 2015. Sistem Informasi Geografis (SIG) Menentukan Lokasi Pertambangan Batu Bara di Provisnsi Bengkulu berbasis Website. Jurnal Media Infotama Volume 11 Nomor 1 . ISSN : 18582680, Hal 51 - 60

Prahasta, Eddy. 2002. Sistem Informasi Geografis: Konsep-Konsep Dasar Informasi Goegrafis. Bandung: Informatika Bandung.
TIM Ems,. 2012. Web Progreming for Beginners. Jakarta: PT Elex Media Komputindo. 